\title{
INFLUENCE OF FEED FORM ON PERFORMANCE IN TWO STRAINS OF BROILER CHICKS
}

\author{
A. A. Enab ${ }^{(1)}$, F.H. Abdou ${ }^{(1)}$, G. A. Zanaty ${ }^{(1)}$ and H.A.A. Elsayed ${ }^{(2)}$ \\ (1) Faculty of Agric., Menoufia Univ., Egypt \\ ${ }^{(2)}$ Ministry of Agriculture and Land Reclamation
}

Received: Sep. 15, 2020

Accepted: Jan. 2,2021

ABSTRACT: The current study was conducted in private poultry farm (area of $120 \mathrm{~m}^{2}$ ), Shibin El-Kom, Menoufia Governorate. The experiment was extended from April to May 2014. The great object of this study was to determine the effect of feed forms on productive and economical efficiency of two broiler strains (Cobb 500 and Ross 308) at ages $7,14,21,28$ and 35 days. Chicks were individually weighted and randomly assigned to 3 experimental groups nearly similar in average body weight $(40 \mathrm{~g})$. The birds of the first, second and third groups were feed on crumble, mash and pellets, respectively. Chicks housed on floor with sawdust. Feed and water were available ad libitun during the experimental period which lasted for 35 days.

Body weights at different ages, growth rates, feed consumption (FC) (kg per bird/cycle), feed conversion ratio FCR, mortality and uniformity were studied. The main results were:

1. For Cobb 500 strain, mash feed had a higher body weight at marketing age (35 days).

2. Ross 308 strain, pellet feed had a higher body weight at marketing age ( 35 days).

3. Ross $\mathbf{3 0 8}$ strain fed on crumble, and Cobb $\mathbf{5 0 0}$ strain fed on mash had lowest mortality $\%$.

4. The best economic efficiency was obtained with pellet feed form for both Cobb $\mathbf{5 0 0}$ and Ross 308.

Key words: Feed forms, Performance, Cobb 500, Ross 308 and Broilers.

\section{INTRODUCTION}

The world population is growing at a frightening level of 220,000 persons / day or $\mathbf{8 0}$ million per year. Asia and Africa are the regions likely to experience the fastest growth, therefore, poultry demand are increased from year to another year. (Fanout and Boekholt, 2018).

The review of the Egyptian broiler industry by the Food and Agriculture Organization of the United Nations (FAO, 2017), aims to inform policy makers and investors both about challenges and opportunities and promote a more efficient and inclusive poultry industry development.

In recent years, the Egyptian poultry production has become an industry rather than an agriculture activity.
Growing consumer demand for affordable animal protein has prompted an increase of broiler chicken meat production in Arab Republic of Egypt.

Feed composition as the most important factor that determines the efficiency of feed utilization by animals. Feed structure (particle size) and feed form (mash, pellets) are also important for the optimal nutrient utilization (Ball et al. 2015). The success or failure of any poultry industry depends to a large extent on feeding. The cost of feeding ranges between $60-70 \%$ of the total cost of production (Willems et al. 2003).

Gracia et al. (2016) mentioned that broilers fed pelleted diets gained more weight than broilers fed mash diets $\mathbf{3 3 . 0}$ vs $44.8 \mathrm{~g} / \mathrm{d}, 67.6 \mathrm{vs} 87.6 \mathrm{~g} / \mathrm{d}$, and $49.4 \mathrm{vs}$ 
$64.8 \mathrm{~g} / \mathrm{d}$ for mash vs pelleted diets from 1-21 d, 22-42 d, and 1-42 d, respectively; $P<0.05)$. Nabi et al. (2017) showed that effect of different feed forms on live body weight of broiler was highly significant $(P \leq 0.01)$ live body weight was higher in broiler of group C (2248.04 $\mathrm{g} / \mathrm{b})$ than group B (with crumble feed 1, 2, and 3 $\mathrm{mm}$ particle size to pre starter) and A (fed with mash as control). Feed conversion ratio was remarkably superior (1.72) in group C (fed with crumble feed 1.5, 2.5 and $3.5 \mathrm{~mm}$ particle size to pre starter), while being moderate (1.81) in broiler of group B, a relatively poor feed conversion ratio of $\mathbf{1 . 8 9}$ was recorded in broiler of group A fed mash feed.

Sogunle et al. (2017) obtained that feed intake of the birds on mash and pellet diets showed no significant $(P \leq 0.05)$ difference with mean values of $97.30 \mathrm{~g} / \mathrm{bird} / \mathrm{day}$ and $110.54 \mathrm{~g} / \mathrm{bird} / \mathrm{day}$ for pellet and mash diets, respectively.

Farghly et al. (2014) found that mortality rate of the four studied groups (Mash, Pellets, Crumbles and Wet) were $10.0,6.6,13.3$ and $6.6 \%$, respectively.

Benyi et al. (2015) found significant superiority of Ross strain (7729 g) to Cobb $(7349 \mathrm{~g})$ at 21 days of age also the same trend was observed at 35 days where Ross weight was $1.809 \mathrm{~kg}$ and $1.791 \mathrm{~kg}$ for Cobb.

Rokonuzzaman et al. (2015), found that the weekly body weight gain of three broiler strains. The Arbor Acres was achieved the highest body weight $76.75 \mathrm{~g}$ in first week followed by $75.75 \mathrm{~g}$ and 73.60g in Cobb-500 and Hubbard Classic broiler strain, respectively. In second weeks Cobb-500 was gain $167.03 \mathrm{~g}$ body weight; it was the highest value in this week than other two strains. They were $407.88 \mathrm{~g}$ body weight gains of Arbor Acres in third weeks, $342.83 \mathrm{~g}$ of Hubbard Classic and $341.60 \mathrm{~g}$ of Cobb-500. The arbor Acres had also highest body weight gain $502.71 \mathrm{~g}$ in fourth weeks, besides $484.14 \mathrm{~g}$ gain in Hubbard Classic and 461.72g gain in Cobb-500.

Singh et al. (2018) mentioned that the highest average live weight of $347.01 \mathrm{~g}$ at $14^{\text {th }}$ day was achieved in Vencobb-400 followed by $345.29 \mathrm{~g}$ in Vencobb and $343.94 \mathrm{~g}$ in Hubbard. Similarly at $28^{\text {th }}$ day the average live weight of Vencobb-400 $(980.80 \mathrm{~g})$ was higher than the Vencobb and Hubbard strains $(979.69 \mathrm{~g}$ and $976.69 \mathrm{~g}$ respectively). At $42^{\text {nd }}$ day, the highest average live weight of $1673.77 \mathrm{~g}$ was found in Vencobb followed by $1658.79 \mathrm{~g}$ in Vencobb-400 and $1655.45 \mathrm{~g}$ in Hubbard. The difference in the live weight of the three broiler strains was found significant $(P \leq 0.05)$ at $14^{\text {th }}, 28^{\text {th }}$ and $42^{\text {nd }}$ day. At $14^{\text {th }}$ and $28^{\text {th }}$ day, the live weight of the Vencobb-400 was found highest; whereas, at $42^{\text {nd }}$ day the live weight was highest in Vencobb.

Kalia, et al. (2017) mentioned that mortalities in each broiler strain in experimental trial $\mathrm{I}$., the mortality rate was recorded highest $(30 \%)$ in Hubbard strain followed by Vencobb (22\%) and RIR cross-bred (16\%). Post-mortem examination of birds revealed $14 \%, 10 \%$, and $6 \%$ mortality induced from ascites and $10 \%, 8 \%$, and $4 \%$ mortality induced from coccidiosis in Hubbard, Vencobb, and RIR cross-bred, respectively.

\section{MATERIALS AND METHODS}

The present study was carried out at private poultry farm (area $120 \mathrm{~m}^{2}$ ), Shibin El-Kom, Menoufia Governorate. The experiment was extended from April to May 2014.

A total number of 1200 , on day old, unsexed, commercial broiler chicks, Cobb 500 (600 birds) and Ross 308 (600 birds) were reared under similar managerial and hygienic conditions. Chicks were individually weight and randomly assigned to 3 experimental 


\section{Influence of feed form on performance in two strains of broiler chicks}

groups nearly similar in average body weight $(\mathbf{4 0 g})$ within each strain. The birds of first second and third groups were fed on crumble, mash and pellet, respectively. Chicks housed on floor with sawdust. Feed and water were available ad libitum during the experimental period which lasted for 35days. This study aimed to evaluate the effect of feed form on productive and economical efficiency of two broiler strains (Cobb 500 and Ross 308 ) at ages 7, 14, 21, 28 and 35 days. On density was applied in open system, 10 birds / $\mathrm{m}^{2}$. The light program was $24 \mathrm{~h}$ (continuous).

All birds were fed the basal diets starter, (1-14 days of age, with $23 \%$ crude protein and $3030 \mathrm{kcal} \mathrm{ME} / \mathrm{kg}$ diet), grower
(14-28 days of age, with $21 \%$ crude protein and $3100 \mathrm{kcal} \mathrm{ME} / \mathrm{kg}$ ), and finisher ( 28 - 35 days), with 19\% crude protein and $3200 \mathrm{kcal} \mathrm{ME} / \mathrm{kg}$ ), according to NRC (1994), as given Table (1).

\section{The studied traits:}

\section{Body weights at different ages:}

Weekly body weights were measured at one day old chicks, then were weighted weekly till 35 days. Each week sample of ( $10 \%$ of total number of birds) was taken randomly and were weighted to estimate average body weight of the dormitories and these samples were applied in all commercial broiler farms.

Table (1): Composition and calculated analysis of commercial diets.

\begin{tabular}{|c|c|c|c|}
\hline Ingredients & $\begin{array}{c}\text { Starter } \\
\text { period } \\
\text { (1-14 days) }\end{array}$ & $\begin{array}{c}\text { Grower } \\
\text { period } \\
\text { (14-28 days) }\end{array}$ & $\begin{array}{c}\text { Finisher } \\
\text { period } \\
(28-35 \text { days })\end{array}$ \\
\hline Ground yellow corn (8.5\%). & 541 & 592.0 & 656.7 \\
\hline Soybean meal, (44\%). & 320 & 260 & 190 \\
\hline Full fat soya. & 29 & 29 & 30 \\
\hline Gluten, (60\%). & 71.5 & 78.0 & 84.9 \\
\hline Mono calcium phosphate. & 16.6 & 17.5 & 15.3 \\
\hline Limestone. & 13 & 13.4 & 11.8 \\
\hline L-lysine. & 1 & 2 & 3 \\
\hline DL-methionine. & 1.2 & 1.4 & 1.6 \\
\hline Salt (NaCl). & 3.7 & 3.7 & 3.7 \\
\hline Premix (Minerals and Vitamins) ${ }^{1}$. & 3 & 3 & 3 \\
\hline Total. & 1000 & 1000 & 1000 \\
\hline \multicolumn{4}{|l|}{ Calculated analysis ${ }^{2}$ : } \\
\hline Crude protein, \%. & 23 & 21 & 19 \\
\hline ME (kcal / kg). & 3030 & 3100 & 3200 \\
\hline Calcium, \%. & 1 & 1.15 & 1.5 \\
\hline Available Phosphorus, \%. & 0.5 & 0.45 & 0.45 \\
\hline
\end{tabular}

${ }^{1}$ Premix. at $0.30 \%$ of the diet supplies the following/ kg of the diet: Vit. A, 12000 IU;Vit.E, 10 mg; Vit. $K_{3}, 3 \mathrm{mg}$; Vit $B_{1}, 1 \mathrm{mg}$; Vit. $B_{2}, 4$ mg; Pantothenic acid, $10 \mathrm{mg}$;Vit. $D_{3}, 2500 \mathrm{IU}$; Nicotinic acid, 20 $\mathrm{mg}$; Folic acid, $1 \mathrm{mg}$; Biotin, $0.05 \mathrm{mg}$; Niacin, $40 \mathrm{mg}$; Vit. $\mathrm{B}_{6}, 3 \mathrm{mg}$; Vit B 12, $0.02 \mathrm{mg}$; Choline chloride, $400 \mathrm{mg}$; Mn, 62 mg; Fe, 44 mg; Zn, 56 mg; I, 1 mg; Cu, 5 mg and Se, 0.01 mg.

${ }^{2}$ Calculated according to NRC (1994). 


\section{Growth Rate (GR):}

Growth rates were estimated intervally at 1-7, 7-14, 14-21, 21-28 and 28-35 days of age, and cumulatively at 1-14, 1-21 and 1-28 days of age using the following formulas (Brody 1945):

$$
\left[\text { Growthrate }=\frac{W_{2}-W_{1}}{1 / 2\left(W_{2}+W_{1}\right)} \times 100\right]
$$

Where:

$\mathrm{W}_{1}=$ First weight

$\mathrm{W}_{2}=$ Second weight

Mortality (M):

Mortality $=\frac{\text { number of died birds }}{\text { total number of the birds in the same week }} \times 100$

\section{Uniformity (UNI):}

Uniformity of BW in broiler breeder flocks is usually determined by individually weighing a sample of birds, calculating the average BW, determining the limits $10 \%$ above and below the average.

Uniformity is a measure of the variability of bird size in a flock. This can be measured by various means, such as:

1. Visual and subjective evaluation

2. By weight $+/-10 \%$

3. By coefficient of variation

\section{Feed consumption (FC):}

The amount of feed consumption per bird per cycle (35 days) was calculated by dividing the total feed consumption during the cycle on the receiving bird numbers in each dormitories.

\section{Feed conversion ratio (FCR):}

The feed conversion ratio was calculated as follow:

$$
F C R=\frac{\text { The feed consumption }(\mathrm{kg}) / \mathrm{bird} / \mathrm{cycle}}{\text { Body weight gain /brid/cycle }(\mathrm{kg})}
$$

while body weight gain was measured as deviation between the body weights (in grams) at $\mathbf{3 5}$ days of age.

\section{Economic efficiency:}

Economical efficiency for broiler production was calculated from the input - out put analysis (Heady and Jensen, 1954), according to the price of the experimental diets and broiler production. Values of economical efficiency were calculated as the net revenue per unit of total costs (Soliman and Abdo, 2005).

\section{Statistical analysis:}

Data were computerized and analyzed according to the following model by SPSS Program (2004). Also significant differences among means were detected by Duncan (1955).

The following fixed model was used:

$Y_{i j k l}=\mu+S_{i}+F_{j}+A_{k}+(S F)_{i j}+(S A)_{i j}+$ $(F A)_{j k}+(S F A)_{i j k}+e_{i j k l}$

Where:

$Y_{\mathrm{ijkl}} \quad$ : Observation of $\mathrm{i}$ strain, $\mathrm{j}$ feed form and $k$ age;

$\mu \quad$ : General mean;

$S_{i} \quad$ : Fixed effect of strain;

$F_{j} \quad:$ Fixed effect of $\left(F_{j}\right)$ feed form;

$A_{k} \quad$ : Fixed effect of $\left(A_{k}\right)$ age

$(S F)_{i j} \quad$ : Effect of interaction $(S F)_{i j}$;

$(S A)_{i k}$ : Effect of interaction (SA) $)_{\mathrm{ik}}$;

$(F A)_{j k}$ : Effect of interaction (FA) $)_{\mathrm{jk}}$;

$(\mathrm{SFA})_{\mathrm{ijk}}$ : Effect of interaction (SFA) $)_{\mathrm{ijk}}$;

$\mathbf{e}_{\mathrm{ijkl}} \quad$ : Residual effect.

\section{RESULTS AND DISCUSSION}

\section{Performance traits:}

Tables (2 a and b) showed analysis of variance of studied traits such as (body weight, growth rate, uniformity, daily mortality, cumulative mortality, daily feed consumption, cumulative feed consumption and feed efficiency) as affected by strains, feed forms and broiler ages. 
Table (2a): Analysis of variance of (BW, GR, UNI, and WM ) traits in broiler chicks.

\begin{tabular}{|c|c|c|c|c|c|c|c|c|}
\hline \multirow{3}{*}{$\begin{array}{l}\text { Source of } \\
\text { variation }\end{array}$} & \multicolumn{8}{|c|}{ Traits $^{1}$} \\
\hline & \multicolumn{2}{|r|}{ BW } & \multicolumn{2}{|c|}{ GR } & \multicolumn{2}{|r|}{ UNI } & \multicolumn{2}{|c|}{ WM } \\
\hline & df & $\begin{array}{l}\text { Mean } \\
\text { square }\end{array}$ & df & $\begin{array}{l}\text { Mean } \\
\text { square }\end{array}$ & df & $\begin{array}{l}\text { Mean } \\
\text { square }\end{array}$ & df & $\begin{array}{l}\text { Mean } \\
\text { square }\end{array}$ \\
\hline Strain (S) & 1 & $44253.8^{* \star}$ & 1 & $12.852^{*}$ & 1 & $9.503^{* *}$ & 1 & $0.006^{* *}$ \\
\hline Feed $(F)$ & 2 & $3356.6^{\star *}$ & 2 & $0.559^{\text {N.S. }}$ & 2 & $123.189^{\star \star}$ & 2 & $0.322^{* *}$ \\
\hline Age (A) & 4 & $19799503.8^{\star *}$ & 4 & $32293.6^{\star *}$ & 4 & $30.648^{\star *}$ & 4 & $0.375^{* *}$ \\
\hline$S^{\star} F$ & 2 & $2503.7^{* \star}$ & 2 & $0.057^{\text {N.S. }}$ & 2 & $54.654^{\star *}$ & 2 & $0.024^{* *}$ \\
\hline$S^{*} A$ & 4 & $13469.7^{\star \star}$ & 4 & $280.9^{\star \star}$ & 4 & $37.922^{\star *}$ & 4 & $0.493^{* *}$ \\
\hline$F^{\star} A$ & 8 & $821.9^{* *}$ & 8 & $14.733^{* *}$ & 8 & $17.417^{\star \star}$ & 8 & $0.480^{* *}$ \\
\hline$S^{*} F^{*} A$ & 8 & $1011.5^{\star \star}$ & 8 & $7.542^{* \star}$ & 8 & $40.291^{\star \star}$ & 8 & $0.328^{* *}$ \\
\hline Error & 114 & 49.4 & 114 & 2.635 & 114 & 0.842 & 114 & 0.000 \\
\hline
\end{tabular}

* Significant $(P \leq 0.05),{ }^{* *}$ highly significant $(P \leq 0.01)$.

${ }^{1} \mathrm{BW}=$ body weight, GR= growth rate, UNI= uniformity, and WM= weekly mortality

Table (2b): Analysis of variance of (CM, WFC, CFC, and FCR ) traits in broiler chicks.

\begin{tabular}{|c|c|c|c|c|c|c|c|c|}
\hline \multirow{3}{*}{$\begin{array}{l}\text { Source of } \\
\text { variation }\end{array}$} & \multicolumn{8}{|c|}{ Traits $^{1}$} \\
\hline & \multicolumn{2}{|c|}{ CM } & \multicolumn{2}{|r|}{ WFC } & \multicolumn{2}{|r|}{ CFC } & \multicolumn{2}{|c|}{ FCR } \\
\hline & df & $\begin{array}{l}\text { Mean } \\
\text { square }\end{array}$ & df & Mean square & df & $\begin{array}{l}\text { Mean } \\
\text { square }\end{array}$ & df & $\begin{array}{l}\text { Mean } \\
\text { square }\end{array}$ \\
\hline Strain (S) & 1 & $0.608^{\star *}$ & 1 & $35973.0^{* *}$ & 1 & $12558.7^{\star \star}$ & 1 & $0.116^{* *}$ \\
\hline Feed (F) & 2 & $9.273^{* \star}$ & 2 & $25382.2^{* \star}$ & 2 & $109847.7^{* *}$ & 2 & $0.128^{* *}$ \\
\hline Age (A) & 4 & $58.918^{* *}$ & 4 & $7513441.5^{* \star}$ & 4 & $61226825.7^{\star \star}$ & 4 & $2.175^{* *}$ \\
\hline$S^{*} F$ & 2 & $10.040^{* *}$ & 2 & $371.3^{* *}$ & 2 & $1593.1^{\star \star}$ & 2 & $0.008^{* *}$ \\
\hline$S^{*} A$ & 4 & $0.168^{* *}$ & 4 & $31652.8^{\star *}$ & 4 & $55946.7^{\star *}$ & 4 & $0.009^{* *}$ \\
\hline$F^{*} A$ & 8 & $0.253^{* *}$ & 8 & $2985.9^{* *}$ & 8 & $20619.3^{* *}$ & 8 & $0.005^{* *}$ \\
\hline$S^{\star} F^{\star} A$ & 8 & $0.246^{* *}$ & 8 & $210.2^{\star \star}$ & 8 & $321.6^{\star}$ & 8 & $0.003^{* *}$ \\
\hline Error & 114 & 0.000 & 114 & 25.1 & 114 & 139.0 & 114 & 0.000 \\
\hline
\end{tabular}

* Significant $(P \leq 0.05)$, ** highly significant $(P \leq 0.01)$.

${ }^{1} \mathrm{CM}=$ cumulative mortality, WFC= weekly feed consumption, $\mathrm{CFC}=$ cumulative feed consumption, and $\mathrm{FCR}=$ feed conversion ratio.

\section{Analysis of variance:}

Table (2a) showed analysis of variance of body weight at different ages $(7,14,21,28$ and 35 days of age) as affected by strains, litters types, feed forms and broiler ages. It is clear that highly significant effect of strains, litters types, feed forms and broiler ages were noticed. 
A. A. Enab, et al.,

\section{Correlations among some performance traits:}

Table (3) showed correlations of studied traits. The Table illustrated that there were highly significant correlations and positive relationships among body weight and both weekly mortality, cumulative mortality, weekly feed consumption, cumulative feed consumption and feed conversion ratio. However, there were highly significant correlations and negative relationships between body weight and both growth rate and uniformity.

It was clear from the Table (3) that there were highly significant correlations and negative relationships between growth rate and both weekly mortality, cumulative mortality, weekly feed consumption, cumulative feed consumption and feed conversion ratio. But, there was no significant correlation with uniformity. There were highly significant correlations and positive relationships among weekly mortality and cumulative mortality, weekly feed consumption, cumulative feed consumption and feed conversion ratio. However, there were highly significant correlations and negative relationships between weekly mortality and uniformity. There were highly significant correlations and positive relationships among cumulative mortality and weekly feed consumption, cumulative feed consumption and feed conversion ratio. However, there were highly significant correlations and negative relationships between cumulative mortality and uniformity. There were highly significant correlations and negative relationships among uniformity and both weekly feed consumption, cumulative feed consumption and feed conversion ratio. Moreover, there were highly significant correlations and positive relationships between weekly feed consumption and cumulative feed consumption and feed conversion ratio.

Effect of the strains, feed forms and ages on body weight:

Effect of strains, feed form and age on body weight of $7,14,21,28$ and 35 days of age are displayed in Table (4). There were highly significant differences for three interactions between strains, feed form and age on body weight ( $P \leq 0.01)$.

Table (3): Correlations among some performance traits.

\begin{tabular}{|l|l|l|l|l|l|l|l|}
\hline \multicolumn{7}{|c|}{ Traits $^{1}$} \\
\hline & BW & GR & WM & CM & UNI & WFC & CFC \\
\hline GR & $-0.946^{* *}$ & & & & & & \\
\hline WM & $0.370^{* *}$ & $-0.254^{* *}$ & & & & & \\
\hline CM & $0.885^{* *}$ & $-0.849^{* *}$ & $0.532^{* *}$ & & & & \\
\hline UNI & $-0.275^{* *}$ & $0.026^{\text {N.S. }}$ & $-0.179^{*}$ & $-0.210^{* *}$ & & & \\
\hline WFC & $0.987^{* *}$ & $-0.968^{* *}$ & $0.390^{* *}$ & $0.896^{* *}$ & $-0.312^{* *}$ & & \\
\hline CFC & $0.996^{* *}$ & $-0.928^{* *}$ & $0.359^{* *}$ & $0.881^{* *}$ & $-0.258^{* *}$ & $0.981^{* *}$ & \\
\hline FCR & $0.887^{* *}$ & $-0.953^{* *}$ & $0.420^{* *}$ & $0.858^{* *}$ & $-0.449^{* *}$ & $0.936^{* *}$ & $0.872^{* *}$ \\
\hline
\end{tabular}

* Significant $(p \leq 0.05),{ }^{* *}$ highly significant $(P \leq 0.01)$.

$1 \mathrm{BW}=$ body weight, $\mathrm{GR}=$ growth rate, $\mathrm{WM}=$ weekly mortality, $\mathrm{CM}=$ cumulative mortality, $\mathrm{UNI}=$ uniformity, and WFC= weekly feed consumption, $\mathrm{CFC}=$ cumulative feed consumption, and FCR $=$ feed conversion ratio. 
Table (4): Body weight ( $\bar{X}_{ \pm} \mathrm{SE}$ ) as affected by interactions among strains, feed form and ages.

\begin{tabular}{|c|l|c|c|c|c|c|}
\hline \multirow{3}{*}{ Strains } & \multirow{5}{*}{ Feed form } & \multicolumn{5}{|c|}{ Ages (days) } \\
\cline { 3 - 7 } & & \multicolumn{5}{|c|}{$\mathrm{g}$} \\
\hline \multirow{4}{*}{ Cobb 500 } & Crumble & $142.5 \pm 5.72^{\mathrm{a}}$ & $382.0 \pm 5.72^{\mathrm{b}}$ & $772.5 \pm 5.72^{\mathrm{b}}$ & $1313.0 \pm 5.72^{\mathrm{b}}$ & $2006.5 \pm 5.72^{\mathrm{b}}$ \\
\cline { 2 - 7 } & Mash & $137.0 \pm 5.72^{\mathrm{b}}$ & $379.0 \pm 8.10^{\mathrm{c}}$ & $786.5 \pm 5.72^{\mathrm{a}}$ & $1335.7 \pm 5.72^{\mathrm{a}}$ & $2072.5 \pm 5.72^{\mathrm{a}}$ \\
\cline { 2 - 7 } & Pellet & $136.0 \pm 5.72^{\mathrm{b}}$ & $384.0 \pm 5.72^{\mathrm{a}}$ & $778.5 \pm 5.72^{\mathrm{b}}$ & $1338.5 \pm 5.72^{\mathrm{a}}$ & $2056.5 \pm 5.72^{\mathrm{a}}$ \\
\hline \multirow{3}{*}{ Ross 308 } & Crumble & $157.0 \pm 5.72^{\mathrm{b}}$ & $421.0 \pm 5.72^{\mathrm{b}}$ & $852.0 \pm 8.10^{\mathrm{b}}$ & $1393.5 \pm 5.72^{\mathrm{b}}$ & $2013.0 \pm 5.72^{\mathrm{b}}$ \\
\cline { 2 - 7 } & Mash & $157.0 \pm 5.72^{\mathrm{b}}$ & $422.0 \pm 5.72^{\mathrm{b}}$ & $832.5 \pm 5.72^{\mathrm{c}}$ & $1376.2 \pm 5.72^{\mathrm{c}}$ & $2009.5 \pm 5.72^{\mathrm{c}}$ \\
\cline { 2 - 7 } & Pellet & $160.5 \pm 5.72^{\mathrm{a}}$ & $442.0 \pm 8.10^{\mathrm{a}}$ & $860.5 \pm 5.72^{\mathrm{a}}$ & $1413.0 \pm 5.72^{\mathrm{a}}$ & $2027.0 \pm 5.72^{\mathrm{a}}$ \\
\hline
\end{tabular}

a,b,c, Differences between values having the same high script in each strain within each column are not significant at $P \leq 0.05$.

Table (4) illustrated that the highest value of body weight was recorded at 7 days of age for Ross 308 strain with pellet feed $(160.5 \pm 5.72 \mathrm{~g})$, followed by Ross 308 strain with crumble feed, Ross 308 strain with mash feed $(157.0 \pm 5.72 \mathrm{~g})$, Cobb 500 strain with crumble feed (142.5 $\pm 5.72 \mathrm{~g}$ ), Cobb 500 strain with mash feed $(137.0 \pm 5.72 \mathrm{~g})$, Cobb 500 strain with pellet feed $(136.0 \pm 5.72 \mathrm{~g})$. The highest value was recorded at 14 days of age for Ross 308 strain with pellet feed $(442.0 \pm$ $8.10 \mathrm{~g})$ followed by Ross 308 strain with mash feed $(422.0 \pm 5.72 \mathrm{~g})$, Ross 308 strain with crumble feed $(421.0 \pm 5.72 \mathrm{~g})$, Cobb 500 strain with pellet feed $(384.0 \pm$ $5.72 \mathrm{~g}$ ), Cobb 500 strain with crumble feed $(382.0 \pm 5.72 \mathrm{~g})$ and Cobb 500 strain with mash feed $(379.0 \pm 8.10 \mathrm{~g})$.

The highest value was recorded at 21 days of age for Ross 308 strain with pellet feed $(860.5 \pm 5.72 \mathrm{~g})$ followed by Ross 308 strain with crumble feed $(852.0$ $\pm 8.10 \mathrm{~g}$ ), Ross 308 strain with mash feed $(832.5 \pm 5.72 \mathrm{~g})$, Cobb 500 strain with mash feed $(786.5 \pm 5.72 \mathrm{~g})$, Cobb 500 strain with pellet feed $(778.5 \pm 5.72 \mathrm{~g})$ and Cobb 500 strain with crumble feed $(772.5$ $\pm 5.72 \mathrm{~g}$ ). The highest value was recorded at 28 days of age for Ross 308 strain with pellet feed $(1413.0 \pm 5.72 \mathrm{~g})$ followed by
Ross 308 strain with crumble feed $(1393.5 \pm 5.72 \mathrm{~g})$, Ross 308 strain with mash feed $(1376.2 \pm 5.72 \mathrm{~g})$, Cobb 500 strain with pellet feed $(1338.5 \pm 5.72 \mathrm{~g})$, Cobb 500 strain with mash feed (1335.7 \pm $5.72 \mathrm{~g}$ ) and Cobb 500 strain with crumble feed $(1313.0 \pm 5.72 \mathrm{~g})$.

However, the highest value was recorded at 35 days of age for Cobb 500 strain with mash feed $(2072.5 \pm 5.72 \mathrm{~g})$ followed by Cobb 500 strain with pellet feed $(2056.5 \pm 5.72 \mathrm{~g})$, Ross 308 strain with pellet feed $(2027.0 \pm 5.72 \mathrm{~g})$, Ross 308 strain with crumble feed (2013.0 \pm $5.72 \mathrm{~g}$ ), Ross 308 strain with mash feed $(2009.5 \pm 5.72 \mathrm{~g})$ and Cobb 500 strain with crumble feed $(2006.5 \pm 5.72 \mathrm{~g})$.

The obtained results were in similar with Cerrate et al. (2009) reported that feed form had a significant effect on BW at $13 \mathrm{~d}$ of age. At that time, birds that had been fed pelleted or crumbled diets were all significantly heavier than birds fed the mash diet. However, after all chicks had been placed on a common pelleted diet, BW at 34 or $41 \mathrm{~d}$ did not differ among birds fed any of the diets during the starter period of 0 to $13 \mathrm{~d}$. Although a statistical difference in BW was not observed at 34 or $41 \mathrm{~d}$, there were 
significant linear regressions between BW at $13 \mathrm{~d}$ and at 34 or $\mathbf{4 1} \mathrm{d}$. The slopes of regression lines indicated that a $1-\mathrm{g}$ change in $B W$ at $13 \mathrm{~d}$ resulted in a corresponding change of 1.5 or $1.8 \mathrm{~g}$ in $B W$ at $34 \mathrm{~d}$ or at $41 \mathrm{~d}$, respectively.

Effect of the interactions among strains, feed forms and ages as affected on growth rate:

Effect of strains, feed form and age on growth rate of 7, 14, 21, 28 and 35 days of age are displayed in Table (5). There were highly significant differences for three interactions between strains, feed form and age on growth rate $(P \leq 0.01)$.

Table (5) illustrated that the highest value of growth rate was recorded at 7 days of age for Ross 308 strain with pellet feed (118.67 $\pm 0.82 \%$ ), followed by Ross 308 strain with crumble feed $(118.50 \pm 0.82 \%)$, Ross 308 strain with mash feed $(117.20 \pm 0.82 \%)$, Cobb 500 strain with crumble feed $(112.07 \pm 0.82$ $\%)$, Cobb 500 strain with mash feed $(108.74 \pm 0.82 \%)$, Cobb 500 strain with pellet feed $(107.40 \pm 0.82 \%)$. The highest value was recorded at 14 days of age for Cobb 500 strain with mash feed (95.51 \pm $1.16 \%$ ) followed by Cobb 500 strain with pellet feed $(95.40 \pm 0.82 \%)$, Ross 308 strain with pellet feed $(94.68 \pm 1.16 \%)$, Ross 308 strain with mash feed (91.46 \pm
$0.82 \%$ ), Ross 308 strain with crumble feed $(91.36 \pm 0.82 \%)$ and Cobb 500 strain with crumble feed $(91.31 \pm 0.82 \%)$.

The highest value was recorded at 21 days of age for Cobb 500 strain with mash feed $(68.54 \pm 0.82 \%)$ followed by Cobb 500 strain with pellet feed $(67.81 \pm$ $0.82 \%$ ), Cobb 500 strain with crumble feed $(67.58 \pm 0.82 \%)$, Ross 308 strain with pellet feed $(64.83 \pm 0.82 \%)$, Ross 308 strain with crumble feed $(65.55 \pm 1.16 \%)$ and Ross 308 strain with mash feed $(65.37 \pm 0.82 \%)$. The highest value was recorded at 28 days of age for Cobb 500 strain with pellet feed $(52.90 \pm 0.82 \%)$ followed by Cobb 500 strain with crumble feed ( $51.84 \pm 0.82 \%)$, Cobb 500 strain with mash feed $(51.75 \pm 0.82 \%)$, Ross 308 strain with mash feed (49.23 \pm $0.82 \%)$, Ross 308 strain with crumble feed (48.72 $\pm 0.82 \%$ ) and Ross 308 strain with pellet feed $(48.60 \pm 0.82 \%)$. However, the highest value was recorded at 35 days of age for Cobb 500 strain with mash feed $(43.24 \pm 0.82 \%)$ followed by Cobb 500 strain with pellet feed $(42.32$ $\pm 0.82 \%$ ), Cobb 500 strain with crumble feed $(41.77 \pm 0.82 \%)$, Ross 308 strain with mash feed (37.42 $\pm 0.82 \%)$, Ross 308 strain with crumble feed $(36.37 \pm 0.82 \%)$ and Ross 308 strain with pellet feed (35.70 $\pm 0.82 \%)$.

Table (5): Growth rate ( $\bar{X}_{ \pm} \mathrm{SE}$ ) as affected by interactions among strains, feed form and ages.

\begin{tabular}{|c|c|c|c|c|c|c|}
\hline \multirow{3}{*}{ Strains } & \multirow{3}{*}{$\begin{array}{l}\text { Feed } \\
\text { form }\end{array}$} & \multicolumn{5}{|c|}{ Ages (days) } \\
\hline & & 7 & 14 & 21 & 28 & 35 \\
\hline & & \multicolumn{5}{|c|}{$\%$} \\
\hline \multirow{3}{*}{$\begin{array}{l}\text { Cobb } \\
500\end{array}$} & Crumble & $112.07 \pm 0.82^{\mathrm{a}}$ & $91.31 \pm 0.82^{b}$ & $67.58 \pm 0.82^{b}$ & $51.84 \pm 0.82^{b}$ & $41.77 \pm 0.82^{b}$ \\
\hline & \begin{tabular}{|l|} 
Mash \\
\end{tabular} & $108.74 \pm 0.82^{b}$ & $95.51 \pm 1.16^{a}$ & $68.54 \pm 0.82^{a}$ & $51.75 \pm 0.82^{b}$ & $43.24 \pm 0.82^{a}$ \\
\hline & Pellet & $107.40 \pm 0.82 b^{b}$ & $95.40 \pm 0.82^{\mathrm{a}}$ & $67.81 \pm 0.82^{b}$ & $52.90 \pm 0.82^{a}$ & $42.32 \pm 0.82^{b}$ \\
\hline \multirow{3}{*}{ Ross 308} & Crumble & $118.50 \pm 0.82^{\mathrm{a}}$ & $91.36 \pm 0.82^{\mathrm{a}}$ & $65.55 \pm 1.16^{\mathrm{a}}$ & $48.72 \pm 0.82^{b}$ & $36.37 \pm 0.82^{b}$ \\
\hline & Mash & $117.20 \pm 0.82^{b}$ & $91.46 \pm 0.82^{a}$ & $65.37 \pm 0.82^{\mathrm{a}}$ & $49.23 \pm 0.82^{a}$ & $37.42 \pm 0.82^{\mathrm{a}}$ \\
\hline & Pellet & $118.67 \pm 0.82^{\mathrm{a}}$ & $94.68 \pm 1.16^{a}$ & $64.83 \pm 0.82^{b}$ & $48.60 \pm 0.82^{b}$ & $35.70 \pm 0.82^{b}$ \\
\hline
\end{tabular}

a,b,c, Differences between values having the same high script in each strain within each column are not significant at $P \leq 0.05$. 
Effect of the interactions among strains, feed forms and ages as affected on uniformity:

Effect of strains, feed form and age on uniformity of $7,14,21,28$ and 35 days of age are displayed in Table (6). There were highly significant differences for three interactions between strains, feed form and age on uniformity $(\mathrm{P} \leq 0.01)$.

Table (6) illustrated that the highest value of uniformity was recorded at 7 days of age for Ross 308 strain with pellet feed $(90.50 \pm 1.03 \%)$, followed by Cobb 500 strain with crumble feed $(86.50$ $\pm 1.03 \%$ ), Cobb 500 strain with pellet feed $(84.50 \pm 1.03 \%)$, Ross 308 strain with crumble feed $(83.00 \pm 1.03 \%)$, Cobb 500 strain with mash feed and Ross 308 strain with mash feed $(82.00 \pm 1.03 \%)$. The highest value was recorded at 14 days of age for Cobb 500 strain with mash feed $(88.00 \pm 1.45 \%)$ followed by Ross 308 strain with crumble feed $\mathbf{8 7 . 5 0}$ $\pm 1.03 \%$ ), Ross 308 strain with mash feed $(86.00 \pm 1.03 \%)$, Cobb 500 strain with crumble feed $(84.50 \pm 1.03 \%)$, Cobb 500 strain with pellet feed $(83.50 \pm 1.03 \%)$ and Ross 308 strain with pellet feed $(82.00 \pm 1.45 \%)$.

The highest value was recorded at 21 days of age for Cobb 500 strain with crumble feed, and Ross 308 strain with pellet feed $(86.00 \pm 1.03 \%)$ followed by Cobb 500 strain with mash feed $(85.50 \pm$ $1.03 \%)$, Cobb 500 strain with pellet feed $(84.50 \pm 1.03 \%)$, Ross 308 strain with crumble feed $(80.00 \pm 1.45 \%)$ and Ross 308 strain with mash feed $(76.00 \pm 1.03$ $\%)$. The highest value was recorded at 28 days of age for Cobb 500 strain with crumble feed, Ross 308 strain with pellet feed $(88.00 \pm 1.03 \%)$ followed by, Cobb 500 strain with pellet feed, Ross 308 strain with mash feed $(85.50 \pm 1.03 \%)$, Cobb 500 strain with mash feed and Ross 308 strain with crumble feed (83.50 \pm $1.03 \%$ ). However, the highest value was recorded at 35 days of age for Ross 308 strain with pellet feed $(87.00 \pm 1.03 \%)$ followed by Cobb 500 strain with pellet feed $(86.50 \pm 1.03 \%)$, Ross 308 strain with crumble feed $(85.50 \pm 1.03 \%)$, Cobb 500 strain with mash feed $(83.00 \pm 1.03$ $\%)$, Ross 308 strain with mash feed (82.50 $\pm 1.03 \%)$ and Cobb 500 strain with crumble feed $(82.00 \pm 1.03 \%)$.

Table (6): Uniformity ( $\bar{X}_{ \pm}$SE) as affected by interactions among strains, feed form and ages.

\begin{tabular}{|c|c|c|c|c|c|c|}
\hline \multirow{3}{*}{ Strains } & \multirow{3}{*}{$\begin{array}{l}\text { Feed } \\
\text { form }\end{array}$} & \multicolumn{5}{|c|}{ Ages (days) } \\
\hline & & 7 & 14 & 21 & 28 & 35 \\
\hline & & \multicolumn{5}{|c|}{$\%$} \\
\hline \multirow{3}{*}{ Cobb 500} & Crumble & $86.50 \pm 1.03^{\mathrm{a}}$ & $84.50 \pm 1.03^{b}$ & $86.00 \pm 1.03^{a}$ & $88.00 \pm 1.03^{a}$ & $82.00 \pm 1.03^{c}$ \\
\hline & Mash & $82.00 \pm 1.03^{c}$ & $88.00 \pm 1.45^{a}$ & $85.50 \pm 1.03^{b}$ & $83.50 \pm 1.03^{c}$ & $83.00 \pm 1.03^{b}$ \\
\hline & Pellet & $84.50 \pm 1.03^{b}$ & $83.50 \pm 1.03^{c}$ & $84.50 \pm 1.03^{c}$ & $85.50 \pm 1.03^{b}$ & $86.50 \pm 1.03^{\mathrm{a}}$ \\
\hline \multirow{3}{*}{ Ross 308} & Crumble & $83.00 \pm 1.03^{b}$ & $87.50 \pm 1.03^{a}$ & $80.00 \pm 1.45^{b}$ & $83.50 \pm 1.03^{c}$ & $85.50 \pm 1.03^{b}$ \\
\hline & Mash & $82.00 \pm 1.03^{c}$ & $86.00 \pm 1.03^{b}$ & $76.00 \pm 1.03^{c}$ & $85.50 \pm 1.03^{b}$ & $82.50 \pm 1.03^{c}$ \\
\hline & Pellet & $90.50 \pm 1.03^{\mathrm{a}}$ & $82.00 \pm 1.45^{c}$ & $86.00 \pm 1.03^{\mathrm{a}}$ & $88.00 \pm 1.03^{a}$ & $87.00 \pm 1.03^{a}$ \\
\hline
\end{tabular}

a,b,c, Differences between values having the same high script in each strain within each column are not significant at $P \leq 0.05$. 
The obtained results were in similar with some researchers such as Lippens et al. (2009) noticed that mash fed Ross 508-chickens in trial 1 only showed a lower uniformity after feed restriction (significant interaction). However, this response was not confirmed in trial 2 (Ross 308). Chehraghi et al. (2013) noticed that weight gain of birds of mash, pellet and crumble group in 1 and 2 weeks of age showed no significant differences. In 3-6 weeks most weight gain related to crumble groups and was significant difference between mash and crumble group. But between mash and pellet, crumble and pellet weight gain of the birds did not differ significantly $(P<0.05)$.

Effect of strains, feed forms and ages as affected on both weekly and cumulative mortality:

Effect of the interaction among strains, feed form and age on both weekly and cumulative mortality of 7,14 , 21,28 and 35 days of age are displayed in Tables (7 and 8 ). There were highly significant differences for three interactions between strains, feed form and age on both weekly and cumulative mortality ( $P \leq 0.01)$.

Table (7) illustrated that the highest value of weekly mortality was recorded at 7 days of age for Cobb 500 strain with crumble feed $(1.13 \pm 0.09 \%)$, followed by Ross 308 strain with pellet feed (1.00 \pm $0.09 \%)$, Cobb 500 strain with pellet feed $(0.87 \pm 0.09 \%)$, Ross 308 strain with mash feed $(0.63 \pm 0.09 \%)$, Ross 308 strain with crumble feed $(0.62 \pm 0.09 \%)$ and Cobb 500 strain with mash feed $(0.50 \pm 0.09 \%)$. The highest value was recorded at 14 days of age for Cobb 500 strain with crumble feed and Ross 308 strain with mash feed $(0.88 \pm 0.09 \%)$ followed by, Cobb 500 strain with mash feed $(0.75 \pm 0.09 \%)$, Cobb 500 strain with pellet feed (0.63 $\pm 0.09 \%)$, Ross 308 strain with crumble feed $(0.50 \pm 0.09 \%)$ and Ross 308 strain with pellet feed $(0.25$ $\pm 0.13 \%$ ). The highest value was recorded at 21 days of age for Ross 308 strain with crumble feed $(1.50 \pm 0.13 \%)$, followed by Ross 308 strain with pellet feed $(1.38 \pm 0.09 \%)$, Cobb 500 strain with mash feed, Ross 308 strain with mash feed $(0.75 \pm 0.09 \%)$, and Cobb 500 strain with pellet feed $(0.63 \pm 0.09 \%)$. The highest value was recorded at 28 days of age for Cobb 500 strain with pellet feed $(1.25 \pm 0.09 \%)$ followed by, Ross 308 strain with crumble feed, Ross 308 strain with pellet feed, Cobb 500 strain with crumble feed $(1.00 \pm 0.09 \%)$, Ross 308 strain with mash feed $(0.88 \pm 0.09 \%)$, and Cobb 500 strain with mash feed $(0.50 \pm$ $0.09 \%)$. However, the highest value was recorded at 35 days of age for Ross 308 strain with crumble feed $(1.13 \pm 0.09 \%)$ followed by Cobb 500 strain with crumble feed, Cobb 500 strain with mash feed, Ross 308 strain with mash feed $(1.00 \pm 0.09 \%)$, Cobb 500 strain with pellet feed $(0.88 \pm 0.09 \%)$, and Ross 308 strain with pellet feed $(0.63 \pm 0.09 \%)$.

Table (8) illustrated that the highest value of cumulative mortality was recorded at 7 days of age for Cobb 500 strain with crumble feed (1.63 $\pm 0.17 \%)$, followed by Cobb 500 strain with pellet feed, Ross 308 strain with pellet feed (1.25 $\pm 0.17 \%)$, Ross 308 strain with crumble feed, Ross 308 strain with mash feed $(0.75 \pm 0.17 \%)$, and Cobb 500 strain with mash feed $(0.50 \pm 0.17 \%)$. The highest value was recorded at 14 days of age for Cobb 500 strain with crumble feed $(2.50 \pm 0.17 \%)$ followed by, Cobb 500 strain with pellet feed $(1.88 \pm 0.17 \%)$, Ross 308 strain with mash feed (1.63 \pm $0.17 \%$ ), Ross 308 strain with pellet feed, Ross 308 strain with crumble feed, and Cobb 500 strain with mash feed (1.25 \pm $0.23 \%$ ). The highest value was recorded at 21 days of age for Cobb 500 strain 


\section{Influence of feed form on performance in two strains of broiler chicks}

with crumble feed (3.25 $\pm 0.17 \%)$, followed by Ross 308 strain with pellet feed $(2.75 \pm 0.17 \%)$,Cobb 500 strain with pellet feed, Ross 308 strain with crumble feed $(2.50 \pm 0.17 \%)$, Ross 308 strain with mash feed $(2.38 \pm 0.17 \%)$, and Cobb 500 strain with mash feed $(1.63 \pm 0.17 \%)$.

The highest value was recorded at 28 days of age for Cobb 500 strain with crumble feed $(4.25 \pm 0.17 \%)$ followed by, Cobb 500 strain with pellet feed, Ross 308 strain with pellet feed $(3.75 \pm 0.17 \%)$, Ross 308 strain with mash feed (3.25 \pm
$0.17 \%$ ), Ross 308 strain with crumble feed $(3.00 \pm 0.17 \%)$, and Cobb 500 strain with mash feed $(2.13 \pm 0.17 \%)$. However, the highest value was recorded at 35 days of age for Cobb 500 strain with crumble feed $(5.25 \pm 0.17 \%)$ followed by Cobb 500 strain with pellet feed $(4.63 \pm$ $0.17 \%)$, Ross 308 strain with pellet feed (4.38 $\pm 0.17 \%)$, Ross 308 strain with mash feed $(4.25 \pm 0.17 \%)$, Ross 308 strain with crumble feed $(4.13 \pm 0.17 \%)$, and Cobb 500 strain with mash feed (3.13 $\pm 0.17 \%)$.

Table (7): Weekly mortality ( $\bar{X}_{ \pm} \mathrm{SE}$ ) as affected by interactions among strains, feed form and ages.

\begin{tabular}{|c|c|c|c|c|c|c|}
\hline \multirow{3}{*}{ Strains } & \multirow{3}{*}{ Feed form } & \multicolumn{5}{|c|}{ Ages (days) } \\
\hline & & 7 & 14 & 21 & 28 & 35 \\
\hline & & \multicolumn{5}{|c|}{$\%$} \\
\hline \multirow{3}{*}{ Cobb 500} & Crumble & $1.13 \pm 0.09^{a}$ & $0.88 \pm 0.09^{a}$ & $0.75 \pm 0.09^{a}$ & $1.00 \pm 0.09^{b}$ & $1.00 \pm 0.09^{a}$ \\
\hline & Mash & $0.50 \pm 0.09^{c}$ & $0.75 \pm 0.13^{b}$ & $0.75 \pm 0.09^{a}$ & $0.50 \pm 0.09^{c}$ & $1.00 \pm 0.09^{a}$ \\
\hline & Pellet & $0.87 \pm 0.09^{b}$ & $0.63 \pm 0.09^{c}$ & $0.63 \pm 0.09^{b}$ & $1.25 \pm 0.09^{\mathrm{a}}$ & $0.88 \pm 0.09^{b}$ \\
\hline \multirow{3}{*}{ Ross 308} & Crumble & $0.62 \pm 0.09^{b}$ & $0.50 \pm 0.09^{b}$ & $1.50 \pm 0.13^{a}$ & $1.00 \pm 0.09^{a}$ & $1.13 \pm 0.09^{a}$ \\
\hline & Mash & $0.63 \pm 0.09^{b}$ & $0.88 \pm 0.09^{a}$ & $0.75 \pm 0.09^{c}$ & $0.88 \pm 0.09^{b}$ & $1.00 \pm 0.09^{b}$ \\
\hline & Pellet & $1.00 \pm 0.09^{\mathrm{a}}$ & $0.25 \pm 0.13^{c}$ & $1.38 \pm 0.09^{b}$ & $1.00 \pm 0.09^{a}$ & $0.63 \pm 0.09^{c}$ \\
\hline
\end{tabular}

a,b,c, Differences between values having the same high script in each strain within each column are not significant at $P \leq 0.05$.

Table (8): Cumulative mortality ( $\bar{X}_{ \pm} \mathrm{SE}$ )as affected by interactions among strains, feed form and ages.

\begin{tabular}{|c|c|c|c|c|c|c|}
\hline \multirow{3}{*}{ Strains } & \multirow{3}{*}{ Feed form } & \multicolumn{5}{|c|}{ Ages (days) } \\
\hline & & 7 & 14 & 21 & 28 & 35 \\
\hline & & \multicolumn{5}{|c|}{$\%$} \\
\hline \multirow{3}{*}{ Cobb 500} & Crumble & $1.63 \pm 0.17^{a}$ & $2.50 \pm 0.17^{a}$ & $3.25 \pm 0.17^{a}$ & $4.25 \pm 0.17^{a}$ & $5.25 \pm 0.17^{\mathrm{a}}$ \\
\hline & Mash & $0.50 \pm 0.17^{c}$ & $1.25 \pm 0.23^{c}$ & $1.63 \pm 0.17^{c}$ & $2.13 \pm 0.17^{c}$ & $3.13 \pm 0.17^{c}$ \\
\hline & Pellet & $1.25 \pm 0.17^{b}$ & $1.88 \pm 0.17^{b}$ & $2.50 \pm 0.17^{b}$ & $3.75 \pm 0.17^{b}$ & $4.63 \pm 0.17^{b}$ \\
\hline \multirow{3}{*}{ Ross 308} & Crumble & $0.75 \pm 0.17^{b}$ & $1.25 \pm 0.17^{b}$ & $2.50 \pm 0.23^{b}$ & $3.00 \pm 0.17^{c}$ & $4.13 \pm 0.17^{c}$ \\
\hline & Mash & $0.75 \pm 0.17^{b}$ & $1.63 \pm 0.17^{a}$ & $2.38 \pm 0.17^{c}$ & $3.25 \pm 0.17^{b}$ & $4.25 \pm 0.17^{b}$ \\
\hline & Pellet & $1.25 \pm 0.17^{a}$ & $1.25 \pm 0.23^{b}$ & $2.75 \pm 0.17^{\mathrm{a}}$ & $3.75 \pm 0.17^{a}$ & $4.38 \pm 0.17^{a}$ \\
\hline
\end{tabular}

$a, b, c$, Differences between values having the same high script in each strain within each column are not significant at $P \leq 0.05$. 
The obtained results were in similar with some researchers such as Cerrate et al. (2009) noticed that there was no significant effect of feed form on mortality. Farghly et al. (2014) found that mortality rate of the four studied groups (mash, pellets, crumbles and wet) were $10.0,6.6,13.3$ and $6.6 \%$, respectively. Namakparvar et al. (2014) studied that the importance of strain with sex and their interaction effect on broiler chickens performance and susceptibility to ascites. Chicks from three strains (Ross 308, Cobb 500 and Arian). They found that strain, sex and their interaction did not significantly effect ascites mortality from 1-14 d. Arian strain showed the highest incidence of ascites mortality $(P<0.01)$ at 15-28, 28-49 $d$ and the entire experimental period.

Effect of strains, feed forms and ages as affected on both weekly and cumulative feed consumption:

Effect of the interaction among strains, feed form and age on both weekly and cumulative feed consumption of 7, 14, 21, 28 and 35 days of age are displayed in Tables (9 and 10). There were highly significant differences for three interactions between strains, feed form and age on both weekly feed consumption $(P \leq 0.01)$ and cumulative feed consumption ( $P \leq 0.05)$.

Table (9) illustrated that the highest value of weekly feed consumption was recorded at 7 days of age for Ross 308 strain with crumble feed $(143.5 \pm 3.94 \mathrm{~g})$, followed by Ross 308 strain with mash feed $(136.5 \pm 3.94 \mathrm{~g})$, Ross 308 strain with pellet feed $(131.5 \pm 3.94 \mathrm{~g})$, Cobb 500 strain with crumble feed $(126.0 \pm 3.94 \mathrm{~g})$, Cobb 500 strain with mash feed (121.0 \pm $3.94 \mathrm{~g}$ ) and Cobb 500 strain with pellet feed $(117.0 \pm 3.94 \mathrm{~g})$. The highest value was recorded at 14 days of age for Ross 308 strain with crumble feed $(389.5 \pm 3.94$ g), followed by Ross 308 strain with mash feed $(373.5 \pm 3.94 \mathrm{~g})$, Ross 308 strain with pellet feed $(366.0 \pm 5.58 \mathrm{~g})$, Cobb 500 strain with crumble feed $(349.5 \pm 3.94 \mathrm{~g})$, Cobb 500 strain with mash feed (342.0 \pm $5.58 \mathrm{~g})$ and Cobb 500 strain with pellet feed $(332.5 \pm 3.94 \mathrm{~g})$.

The highest value was recorded at 21 days of age for Cobb 500 strain with crumble feed $(676.5 \pm 3.94 \mathrm{~g})$, followed by Ross 308 strain with crumble feed $\mathbf{6 7 3 . 0}$ $\pm 5.58 \mathrm{~g}$ ), Cobb 500 strain with mash feed $(656.0 \pm 3.94 \mathrm{~g})$, Ross 308 strain with mash feed $(648.5 \pm 3.94 \mathrm{~g})$, Cobb 500 strain with pellet feed $(641.5 \pm 3.94 \mathrm{~g})$ and Ross 308 strain with pellet feed (629.5 \pm $3.94 \mathrm{~g})$. The highest value was recorded at 28 days of age for Cobb 500 strain with crumble feed $(1067.0 \pm 3.94 \mathrm{~g})$, followed by Cobb 500 strain with mash feed $(1035.0 \pm 3.94 \mathrm{~g})$, Cobb 500 strain with pellet feed $(1012.5 \pm 3.94 \mathrm{~g})$, Ross 308 strain with crumble feed $(990.0 \pm 3.94$ g), Ross 308 strain with mash feed (948.2 $\pm 3.94 \mathrm{~g}$ ) and Ross 308 strain with pellet feed $(929.5 \pm 3.94 \mathrm{~g})$. However, the highest value was recorded at 35 days of age for Cobb 500 strain with crumble feed $(1376.5 \pm 3.94 \mathrm{~g})$, followed by Cobb 500 strain with mash feed $(1328.0 \pm 3.94$ g), Cobb 500 strain with pellet feed $(1301.5 \pm 3.94 \mathrm{~g})$, Ross 308 strain with crumble feed (1273.5 $\pm 3.94 \mathrm{~g}$ ), Ross 308 strain with mash feed $(1230.0 \pm 3.94 \mathrm{~g})$ and Ross 308 strain with pellet feed $(1167.5 \pm 3.94 \mathrm{~g})$.

Table (10) illustrated that the highest value of cumulative feed consumption was recorded at 7 days of age for Ross 308 strain with crumble feed $(173.5 \pm 7.08$ g), followed by Ross 308 strain with mash feed $(167.0 \pm 7.08 \mathrm{~g})$, Ross 308 strain with pellet feed (162.5 $\pm 7.08 \mathrm{~g})$, Cobb 500 strain with crumble feed, Cobb 500 strain with mash feed $(151.5 \pm 7.08 \mathrm{~g})$, and Cobb 500 strain with pellet feed $(148.0 \pm 7.08$ g). The highest value was recorded at 14 days of age for Ross 308 strain with crumble feed $(563.0 \pm 7.08 \mathrm{~g})$, followed by Ross 308 strain with mash feed (540.5 \pm $7.08 \mathrm{~g}$ ), Ross 308 strain with pellet feed $(529.0 \pm 10.01 \mathrm{~g})$, Cobb 500 strain with crumble feed $(505.0 \pm 7.08 \mathrm{~g})$, Cobb 500 


\section{Influence of feed form on performance in two strains of broiler chicks}

strain with mash feed (494.7 $\pm 10.01 \mathrm{~g})$ and Cobb 500 strain with pellet feed $(480.5 \pm 7.08 \mathrm{~g})$.

The highest value was recorded at 21 days of age for Ross 308 strain with crumble feed (1234.0 $\pm 10.01 \mathrm{~g})$, followed by Ross 308 strain with mash feed $(1189.0 \pm 7.08 \mathrm{~g})$, Cobb 500 strain with crumble feed $(1182.5 \pm 7.08 \mathrm{~g})$, Cobb 500 strain with crumble feed (1182.5 $\pm 7.08 \mathrm{~g})$, Ross 308 strain with pellet feed (1154.5 \pm $7.08 \mathrm{~g}$ ), Cobb 500 strain with mash feed (1148.3 $\pm 7.08 \mathrm{~g})$ and Cobb 500 strain with pellet feed $(1122.0 \pm 7.08 \mathrm{~g})$. The highest value was recorded at 28 days of age for Cobb 500 strain with crumble feed $(2249.5 \pm 7.08 \mathrm{~g})$, followed by Ross
308 strain with crumble feed (2223.0 \pm $7.08 \mathrm{~g}$ ), Cobb 500 strain with mash feed $(2183.2 \pm 7.08 \mathrm{~g})$, Ross 308 strain with mash feed (2137.2 $\pm 7.08 \mathrm{~g})$, Cobb 500 strain with pellet feed $(2134.5 \pm 7.08 \mathrm{~g})$ and Ross 308 strain with pellet feed $(2084.0 \pm 7.08 \mathrm{~g})$. However, the highest value was recorded at 35 days of age for Cobb 500 strain with crumble feed (3626.0 $\pm 7.08 \mathrm{~g})$, followed by Cobb 500 strain with mash feed (3511.0 $\pm 7.08 \mathrm{~g})$, Ross 308 strain with crumble feed (3496.5 $\pm 7.08 \mathrm{~g})$, Cobb 500 strain with pellet feed $(3436.0 \pm 7.08 \mathrm{~g})$, Ross 308 strain with mash feed (3367.0 $\pm 7.08 \mathrm{~g})$ and Ross 308 strain with pellet feed (3251.5 $\pm 7.08 \mathrm{~g})$.

Table (9): Weekly feed consumption ( $\bar{X} \pm \mathrm{SE}$ ) as affected by interactions among strains, feed form and ages.

\begin{tabular}{|c|c|c|c|c|c|c|}
\hline \multirow{3}{*}{ Strains } & \multirow{3}{*}{$\begin{array}{l}\text { Feed } \\
\text { form }\end{array}$} & \multicolumn{5}{|c|}{ Ages (days) } \\
\hline & & 7 & 14 & 21 & 28 & 35 \\
\hline & & \multicolumn{5}{|c|}{ g } \\
\hline \multirow{3}{*}{ Cobb 500} & Crumble & $126.0 \pm 3.94^{\mathrm{a}}$ & $349.5 \pm 3.94^{\mathrm{a}}$ & $676.5 \pm 3.94^{\mathrm{a}}$ & $1067.0 \pm 3.94^{a}$ & $1376.5 \pm 3.94^{a}$ \\
\hline & Mash & $121.0 \pm 3.94^{b}$ & $342.0 \pm 5.58^{b}$ & $656.0 \pm 3.94^{\mathrm{b}}$ & $1035.0 \pm 3.94^{b}$ & $1328.0 \pm 3.94^{b}$ \\
\hline & Pellet & $117.0 \pm 3.94^{c}$ & $332.5 \pm 3.94^{c}$ & $641.5 \pm 3.94^{c}$ & $1012.5 \pm 3.94^{c}$ & $1301.5 \pm 3.94^{c}$ \\
\hline \multirow{3}{*}{ Ross 308} & Crumble & $143.5 \pm 3.94^{\mathrm{a}}$ & $389.5 \pm 3.94^{\mathrm{a}}$ & $673.0 \pm 5.58^{a}$ & $990.0 \pm 3.94^{\mathrm{a}}$ & $1273.5 \pm 3.94^{a}$ \\
\hline & Mash & $136.5 \pm 3.94^{b}$ & $373.5 \pm 3.94^{b}$ & $648.5 \pm 3.94^{b}$ & $948.2 \pm 3.94^{b}$ & $1230.0 \pm 3.94^{b}$ \\
\hline & Pellet & $131.5 \pm 3.94^{c}$ & $366.0 \pm 5.58^{c}$ & $629.5 \pm 3.94^{c}$ & $929.5 \pm 3.94^{c}$ & $1167.5 \pm 3.94^{c}$ \\
\hline
\end{tabular}

a,b,c, Differences between values having the same high script in each strain within each column are not significant at $P \leq \mathbf{0 . 0 5}$.

Table (10): Cumulative feed consumption $\left(\bar{X}_{ \pm}\right.$SE) as affected by interactions among strains, feed form and ages.

\begin{tabular}{|c|l|l|c|c|c|c|}
\hline \multirow{3}{*}{ Strains } & \multirow{2}{*}{$\begin{array}{l}\text { Feed } \\
\text { form }\end{array}$} & \multicolumn{5}{|c|}{ Ages (days) } \\
\cline { 3 - 7 } & & 7 & 14 & 21 & 28 & 35 \\
\cline { 2 - 7 } & & \multicolumn{5}{|c|}{$\mathrm{g}$} \\
\hline \multirow{3}{*}{ Cobb 500 } & Crumble & $151.5 \pm 7.08^{\mathrm{a}}$ & $505.0 \pm 7.08^{\mathrm{a}}$ & $1182.5 \pm 7.08^{\mathrm{a}}$ & $2249.5 \pm 7.08^{\mathrm{a}}$ & $3626.0 \pm 7.08^{\mathrm{a}}$ \\
\cline { 2 - 7 } & Mash & $151.5 \pm 7.08^{\mathrm{a}}$ & $494.7 \pm 10.01^{\mathrm{b}}$ & $1148.3 \pm 7.08^{\mathrm{b}}$ & $2183.2 \pm 7.08^{\mathrm{b}}$ & $3511.0 \pm 7.08^{\mathrm{b}}$ \\
\cline { 2 - 7 } & Pellet & $148.0 \pm 7.08^{\mathrm{b}}$ & $480.5 \pm 7.08^{\mathrm{c}}$ & $1122.0 \pm 7.08^{\mathrm{c}}$ & $2134.5 \pm 7.08^{\mathrm{c}}$ & $3436.0 \pm 7.08^{\mathrm{c}}$ \\
\hline \multirow{3}{*}{ Ross 308 } & Crumble & $173.5 \pm 7.08^{\mathrm{a}}$ & $563.0 \pm 7.08^{\mathrm{a}}$ & $1234.0 \pm 10.01^{\mathrm{a}}$ & $2223.0 \pm 7.08^{\mathrm{a}}$ & $3496.5 \pm 7.08^{\mathrm{a}}$ \\
\cline { 2 - 7 } & Mash & $167.0 \pm 7.08^{\mathrm{b}}$ & $540.5 \pm 7.08^{\mathrm{b}}$ & $1189.0 \pm 7.08^{\mathrm{b}}$ & $2137.2 \pm 7.08^{\mathrm{b}}$ & $3367.0 \pm 7.08^{\mathrm{b}}$ \\
\cline { 2 - 7 } & Pellet & $162.5 \pm 7.08^{\mathrm{c}}$ & $529.0 \pm 10.01^{\mathrm{c}}$ & $1154.5 \pm 7.08^{\mathrm{c}}$ & $2084.0 \pm 7.08^{\mathrm{c}}$ & $3251.5 \pm 7.08^{\mathrm{c}}$ \\
\hline
\end{tabular}

a,b,c, Differences between values having the same high script in each strain within each column are not significant at $P \leq 0.05$. 
The obtained results were in similar with some researchers such as Cerrate et al. (2009) reported that birds fed diets pelleted with 1.59 - or $3.17-\mathrm{mm}$ dies had higher feed consumption than birds fed mash, but the feed intake was similar when birds were fed either a crumble or mash diet. Significant linear regressions were observed between feed intake at 13 $\mathrm{d}$ and at 34 or $41 \mathrm{~d}$. The slopes of regression lines indicated that a $1-\mathrm{g}$ change in feed intake at $13 \mathrm{~d}$ resulted in a corresponding change of 4.2 or $5.9 \mathrm{~g}$ in feed intake at 34 or $41 \mathrm{~d}$, respectively. Chehraghi et al. (2013) noticed that there were significant differences in 1and 2 week feed intake among the three dietary groups. In 3-6 weeks the highest and the lowest feed intake were observed in crumble and pellet group as well as mash group respectively that among crumble and mash group, pellet and mash group were significant differences $(p<0.05)$. There were significant differences in 1and 2 week feed intake among the three dietary groups. In 3-6 weeks the highest feed intake were observed in pellet and the lowest feed intake were observed in crumble and mash group. Among all of the group were significant differences $(p<0.05)$. Al-Nasrawi $(2016)$ noticed that $\mathrm{FI}$, of broiler chicks fed on crumble, pellet and mash diets. The results revealed that broilers fed crumble and pellet consumed more ( $P \leq 0.05)$ feed from 22 to $32 \mathrm{~d}, 33$ to $42 \mathrm{~d}$, and 1 to $42 \mathrm{~d}$ as compared with mash. Broiler chicks fed crumble had the highest FI $(2085.28 \mathrm{~g})$ in 22-32 d. The corresponding estimations for $\mathrm{FI}$ was 1369.97 in $33-42 \mathrm{~d}$ and $4300.07 \mathrm{~g}$ in $1-42$ d.

\section{Effect of strains, feed forms and ages as affected on feed conversion ratio:}

Effect of the interaction among strains, feed form and age on feed conversion ratio of $7,14,21,28$ and 35 days of age are displayed in Table (13). There were highly significant differences for three interactions between strains, feed form and age on feed conversion ratio $(P \leq 0.01)$.

Table (11) illustrated that the worst value of feed conversion ratio was recorded at 7 days of age for Ross 308 strain with crumble feed, Cobb 500 strain with mash feed $(1.11 \pm 0.011 \mathrm{~g}$ feed $/ \mathrm{g}$ gain), followed by Cobb 500 strain with pellet feed $(1.09 \pm 0.011 \mathrm{~g}$ feed $/ \mathrm{g}$ gain), Ross 308 strain with mash feed, Cobb 500 strain with crumble feed (1.06 \pm $0.011 \mathrm{~g}$ feed $/ \mathrm{g}$ gain), and Ross 308 strain with pellet feed $(1.01 \pm 0.011 \mathrm{~g}$ feed $/ \mathrm{g}$ gain). The worst value was recorded at 14 days of age for Ross 308 strain with crumble feed (1.34 $\pm 0.011 \mathrm{~g}$ feed $/ \mathrm{g}$ gain), followed by Cobb 500 strain with crumble feed (1.32 $\pm 0.011 \mathrm{~g}$ feed $/ \mathrm{g}$ gain), Cobb 500 strain with mash feed (1.31 \pm $0.016 \%)$, Ross 308 strain with mash feed $(1.28 \pm 0.011 \mathrm{~g}$ feed $/ \mathrm{g}$ gain), Cobb 500 strain with pellet feed $(1.25 \pm 0.011 \%)$ and Ross 308 strain with pellet feed ( 1.20 $\pm 0.016 \mathrm{~g}$ feed/ $\mathrm{g}$ gain).

The worst value was recorded at 21 days of age for Cobb 500 strain with crumble feed (1.53 $\pm 0.011 \mathrm{~g}$ feed/ $\mathrm{g}$ gain), followed by Cobb 500 strain with mash feed $(1.46 \pm 0.011 \mathrm{~g}$ feed $/ \mathrm{g}$ gain), Ross 308 strain with pellet feed $(1.45 \pm 0.016 \mathrm{~g}$ feed/ g gain), Cobb 500 strain with pellet feed $(1.44 \pm 0.011 \mathrm{~g}$ feed $/ \mathrm{g}$ gain), Ross 308 strain with mash feed $(1.43 \pm 0.011 \mathrm{~g}$ feed/g gain) and Ross 308 strain with pellet feed $(1.34 \pm 0.011 \mathrm{~g}$ feed/ $\mathrm{g}$ gain). The worst value was recorded at 28 days of age for Cobb 500 strain with crumble feed (1.71 $\pm 0.011 \mathrm{~g}$ feed/ $\mathrm{g}$ gain), followed by Cobb 500 strain with mash feed $(1.64 \pm 0.011 \mathrm{~g}$ feed $/ \mathrm{g}$ gain), Cobb 500 strain with pellet feed, Ross 308 strain with crumble feed $(1.60 \pm 0.011 \mathrm{~g}$ feed/ g gain), Ross 308 strain with mash feed $(1.55 \pm 0.011 \mathrm{~g}$ feed/ $\mathrm{g}$ gain) and Ross 308 strain with pellet feed (1.48 \pm 
$0.011 \mathrm{~g}$ feed/ $\mathrm{g}$ gain). However, the worst value was recorded at 35 days of age for Cobb 500 strain with crumble feed (1.81 $\pm 0.011 \mathrm{~g}$ feed/ $\mathrm{g}$ gain), followed by Ross 308 strain with crumble feed $(1.74 \pm 0.011$ $\mathrm{g}$ feed/ g gain), Cobb 500 strain with mash feed $(1.69 \pm 0.011 \mathrm{~g}$ feed $/ \mathrm{g}$ gain), Ross 308 strain with mash feed (1.68 \pm $0.011 \mathrm{~g}$ feed $/ \mathrm{g}$ gain), Cobb 500 strain with pellet feed $(1.67 \pm 0.011 \%)$, and Ross 308 strain with pellet feed (1.60 \pm $0.011 \mathrm{~g}$ feed $/ \mathrm{g}$ gain).

From the obtained results, Ross 308 strain with pellet feed form had the best feed conversion ratio for all ages compared to the Cobb 500 strain with the other feed forms.

The obtained results were in similar with some researchers such as Pirzado et al. (2015), found that feed conversion ratio (FCR) was observed as $1.61 \pm 0.01$

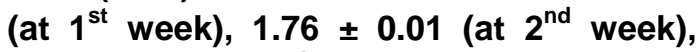
$1.69 \pm 0.02$ (at $3^{\text {rd }}$ week) and $1.86 \pm 1.00$ (at $4^{\text {th }}$ week) in broilers fed mash, while in broilers fed crumbles it was $1.64 \pm 0.01$, $1.81 \pm 0.01,1.73 \pm 0.00$ and $1.87 \pm 1.00$ at corresponding weeks. However FCR was improved in group of broilers fed crumbles at $5^{\text {th }}$ week $(1.93 \pm 8.81)$ and $6^{\text {th }}$ $(2.03 \pm 0.02)$ week as compared to broilers with mash at $5^{\text {th }}$ and $6^{\text {th }}$ week
$(2.15 \pm 0.02$ and $2.19 \pm 5.78$, respectively) . FCR was recorded to be comparatively better $(P<0.05)$ in broilers with crumble feeding $(1.84 \pm 3.33)$ than broilers with mash (1.88 \pm 6.67). Al-Nasrawi (2016) noticed that FCR of broiler chicks fed on crumble, pellet and mash diets, broilers fed crumble and pellet diet grew faster $(P$ $\leq 0.05)$, consumed more $(P \leq 0.05)$ feed and have lower FCR from 22 to $32 \mathrm{~d}, 33$ to $42 \mathrm{~d}$, and 1 to $42 \mathrm{~d}$ as compared with mash. Broiler chicks fed crumble had the best FCR (2.01) in 22-32 d. The corresponding estimations FCR was 2.38 in 33-42 d and 2.05 in 1-42 d.

\section{Economic efficiency:}

Results of feeding cost for chicks feed with different feed forms are presented in Tables (12 and 13). Best economic efficiency was obtained with pellet feed form for both Cobb 500 and Ross 308 (160.98 and $172.14 \%$, respectively) followed by mash feed form for both Cobb 500 and Ross 308 (156.96 and $159.81 \%$, respectively) and crumble feed form for both Cobb 500 and Ross 308 (141.13 and $150.16 \%$, respectively). However, this depends on feed form which improved of feed conversion ratio.

Table (11): Feed conversion ratio ( $\left.\bar{X}_{ \pm} \mathrm{SE}\right)$ as affected by interactions among strains, feed form and ages.

\begin{tabular}{|l|l|l|c|c|c|c|}
\hline \multirow{3}{*}{ Strains } & \multirow{5}{*}{ Feed form } & \multicolumn{5}{|c|}{ Ages (days) } \\
\cline { 3 - 7 } & & 7 & 14 & 21 & 28 & 35 \\
\cline { 2 - 7 } & & \multicolumn{5}{|c|}{ g feed/g gain } \\
\hline \multirow{3}{*}{$\begin{array}{l}\text { Cobb } \\
500\end{array}$} & Crumble & $1.06 \pm 0.011^{\mathrm{a}}$ & $1.32 \pm 0.011^{\mathrm{a}}$ & $1.53 \pm 0.011^{\mathrm{a}}$ & $1.71 \pm 0.011^{\mathrm{a}}$ & $1.81 \pm 0.011^{\mathrm{a}}$ \\
\cline { 2 - 7 } & Mash & $1.11 \pm 0.011^{\mathrm{b}}$ & $1.31 \pm 0.016^{\mathrm{a}}$ & $1.46 \pm 0.011^{\mathrm{b}}$ & $1.64 \pm 0.011^{\mathrm{b}}$ & $1.69 \pm 0.011^{\mathrm{b}}$ \\
\cline { 2 - 7 } & Pellet & $1.09 \pm 0.011^{\mathrm{c}}$ & $1.25 \pm 0.011^{\mathrm{b}}$ & $1.44 \pm 0.011^{\mathrm{b}}$ & $1.60 \pm 0.011^{\mathrm{c}}$ & $1.67 \pm 0.011^{\mathrm{c}}$ \\
\hline \multirow{3}{*}{$\begin{array}{l}\text { Ross } \\
308\end{array}$} & Crumble & $1.11 \pm 0.011^{\mathrm{a}}$ & $1.34 \pm 0.011^{\mathrm{a}}$ & $1.45 \pm 0.016^{\mathrm{a}}$ & $1.60 \pm 0.011^{\mathrm{a}}$ & $1.74 \pm 0.011^{\mathrm{a}}$ \\
\cline { 2 - 7 } & Mash & $1.06 \pm 0.011^{\mathrm{b}}$ & $1.28 \pm 0.011^{\mathrm{b}}$ & $1.43 \pm 0.011^{\mathrm{a}}$ & $1.55 \pm 0.011^{\mathrm{b}}$ & $1.68 \pm 0.011^{\mathrm{b}}$ \\
\cline { 2 - 7 } & Pellet & $1.01 \pm 0.011^{\mathrm{b}}$ & $1.20 \pm 0.016^{\mathrm{c}}$ & $1.34 \pm 0.011^{\mathrm{b}}$ & $1.48 \pm 0.011^{\mathrm{c}}$ & $1.60 \pm 0.011^{\mathrm{c}}$ \\
\hline
\end{tabular}

a,b,c, Differences between values having the same high script in each strain within each column are not significant at $P \leq 0.05$. 
A. A. Enab, et al.,

Table (12): Effect of feed forms on the economic efficiency of Cobb 500 at 35 days of age.

\begin{tabular}{|l|c|c|c|}
\hline \multirow{2}{*}{\multicolumn{1}{|c|}{ Items }} & \multicolumn{3}{|c|}{ Feed forms } \\
\cline { 2 - 4 } & Crumble & Mash & Pellet \\
\hline Initial body weight, g. & 40.0 & 40.0 & 40.0 \\
\hline Final body weight, kg. & 2.01 & 2.07 & 2.06 \\
\hline Body weight gain, kg & 1.97 & 2.03 & 2.02 \\
\hline Total revenue ${ }^{1}$, L.E. & 39.40 & 40.60 & 40.40 \\
\hline Feed intake, kg. & 3.63 & 3.51 & 3.44 \\
\hline Price of one kg feed , L.E. $^{*}$ Feed cost $^{2}$, L.E. & 4.5 & 4.5 & 4.5 \\
\hline Net revenue $^{3}$, L.E. & 16.34 & 15.80 & 15.48 \\
\hline Economic efficiency $^{4}$, \%. & 23.06 & 24.80 & 24.92 \\
\hline
\end{tabular}

Price of one $\mathrm{kg}$ live body weight 20L.E./ $\mathrm{kg}$ at time of experiment.

${ }^{1}$ Total revenue $=$ live body weight $\times$ marketing price.

${ }^{2}$ Feed cost $=$ feed intake $\times$ price of $\mathbf{k g}$ feed.

${ }^{3}$ Net revenue $=$ Total revenue - Feed cost.

${ }^{4}$ Economical efficiency $=($ Net revenue $/$ Feed cost $) \times 100$.

Table (13): Effect of feed forms on the economic efficiency of Ross 308 at 35 days of age.

\begin{tabular}{|l|c|c|c|}
\hline \multirow{2}{*}{\multicolumn{1}{|c|}{ Items }} & \multicolumn{3}{|c|}{ Feed forms } \\
\cline { 2 - 4 } & Crumble & Mash & Pellet \\
\hline Initial body weight, g. & 40 & 40 & 40 \\
\hline Final body weight, kg. & 2.01 & 2.01 & 2.03 \\
\hline Body weight gain, $\mathrm{kg}$ & 1.97 & 1.97 & 1.99 \\
\hline Total revenue ${ }^{1}$, L.E. & 40.26 & 40.19 & 40.54 \\
\hline Feed intake, kg. & 3.5 & 3.37 & 3.25 \\
\hline Price of one kg feed , L.E. $^{*}$ Feed cost ${ }^{2}$, L.E. & 4.5 & 4.5 & 4.5 \\
\hline Net revenue $^{3}$, L.E. & 15.75 & 15.17 & 14.63 \\
\hline Economic efficiency $^{4}, \%$. & 23.65 & 24.24 & 25.18 \\
\hline
\end{tabular}

Price of one $\mathrm{kg}$ live body weight 20L.E./ $\mathrm{kg}$ at time of experiment.

${ }^{1}$ Total revenue $=$ live body weight $\times$ marketing price

${ }^{2}$ Feed cost $=$ feed intake $\times$ price of $\mathbf{k g}$ feed.

${ }^{3}$ Net revenue $=$ Total revenue - Feed cost.

${ }^{4}$ Economical efficiency $=($ Net revenue $/$ Feed cost $) \times 100$. 
In general, the results showed that:

- For Cobb 500 strain, mash feed had a higher body weight at marketing age. But for Ross 308 strain, pellet feed had a higher body weight at marketing age.

- Ross 308 strain fed on crumble, and Cobb 500 strain fed on mash had lowest mortality \%.

- The best economic efficiency was obtained with pellet feed form for both Cobb 500 and Ross 308 strains

\section{REFERENCES}

Al-Nasrawi, M. A. M. (2016). The impact of different dietary forms (mash, crumble and pellets) on some growth traits and carcass characteristics of broilers. J. Anim. Heal. and Prod., 4 (2): 31-36.

Ball, M.E.E., E. Magowan, K.J. McCracken, V.E. Beattie, and R. Bradford, (2015). An investigation into the effect of dietary particle size and pelleting of diets for finishing pigs. Livest. Sci., 173: 48-54.

Benyi, K., J. N. Avhafunani, T.M. Kgabo and T.G. Eastonce (2015). Effect of genotype and stocking density on broiler performance during two subtropical seasons. Trop. Anim. Heal. Prod., 47:969-974.

Brody, S. (1945). Bioenergetic and growth. Reinnold Pub. Crop. New York.

Cerrate, S., Z. Wang, C. Coto, F. Yan and P. W. Waldroup (2009). Effect of pellet diameter in broiler starter diets on subsequent performance. J. Appl. Poult. Res., 18 :590-597

Chehraghi, M., A. Zakeri and M. Taghinejad-Roudbaneh (2013). ffects of different feed forms on performance in broiler chickens Euro. J. Exper. Bio., 3(4):66-70.

Duncan, D. B. (1955). Multiple ranges and multiple $F$ test. Biometrics (11): 1-42.
Fanout, F. and P. V. Boekholf (2018). The challenging world of primary breeding matching genetic to market requirements. Zootecnica. Vol 4: 3638.

FAO, (2017). Broiler poultry industry: investment challenges and opportunities.

Farghly, M. F. A., O. S. Afifi and H.H. M. Hassanien (2014). Effect of feed form on broiler chicks performance. $7^{\text {th }}$ International Poultry Conference. 3 - 6 November 2014, Ain Sukhna, Red Sea - Egypt. 49-57.

Gracia, M. I., J. Sánchez, C. Millán, Ó. Casabuena, P. Vesseur, Á. Martín, F. J. García-Peña and P. Medel (2016). Effect of feed form and whole grain feeding on gastrointestinal weight and the prevalence of campylobacter Jejuni in broilers orally infected. Campylobacter Control in Broilers. 117

Heady, E.O. and H.K. Jensen (1954). Farm management Economics. Pentice-Hall Inc. Englewood Ctiffs N.J., USA.

Kalia, S., V.K. Bharti, D. Gogoi, A. Giri and B. Kumar (2017). Studies on the growth performance of different broiler strains at high altitude and evaluation of probiotic effect on their survivability. Scientific reports. 1-8.

Lippens, M., E. Delezie, L. Maertens and G. Huyghebaert, (2009). Influence of feed texture and early quantitative feed restriction on performance, growth development and carcass composition of two broiler strains. Arch.Geflügelk., 73 (1). S. 29-40.

Nabi, F., M. I. Rind, J. Li, M. Zulqarnain, M. Shahzad, N. Ahmed, M. K. Iqbal and M. U. Rehman. (2017). Influence of different feed forms and particle size on efficiency of broiler production. Online J. Anim. Feed Res., 7(2): 24-28.

Namakparvar, R., F. Shariatmadari and S. H. Hossieni (2014). Strain with sex 
A. A. Enab, et al.,

effects on ascites development in commercial broiler chickens. Iranian Journal of Veterinary Research, Shiraz University. 15(47): 116-121.

NRC (1994). Nutrients Requirements of poultry $\left(7^{\text {th }}\right.$ rev.) Washington: Natl. Acad. Press. Washington. D.C.

Pirzado, S. A., A. S. Mangsi2, G. S. Barham, G. M. Mari3, Z. Pirzado and Q. Kalwar (2015). Effect of mash and crumbled feed forms on the performance of broiler chickens. IOSR J. Agric. and Vet. Sci., 8(12): 27-30.

Rokonuzzaman, M., S. S. Jahan, M. S. Ali, M. A. Islam and M. S. Islam (2015). Growth performance of three broiler strains in winter seasons in Bangladesh. Inter. J. Agric. Pol. and Res., 3(7): 308-313.

Singh, D. K., V. K. Singh and V. K. Paswan (2018). Comparative production performance of three fast growing broiler strains in the rainy season of Eastern Uttar Pradesh. Inter J. Livestock Res., 8(10), 205-211

Sogunle, O. M., O. J. Odutayo, S. T. Aremu, K. K. Safiyu and A. I. lyanda (2017). Effects of two feed forms on the growth performance, carcass yield and duodenal villus morphology of locally-adapted turkeys. Bull. Anim. HIth. Prod. Afr., 65: 117-123

Soliman, A.Z.M. and M.A. Zeinab Abdo (2005). Evaluation of fresh garlic as natural feed additive in layer diets varying in energy con tent. Egypt. Poult. Sci., 25 (II): 317-331.

SPSS Program (2004). User's guide statistic. Release 10.01, Copyright SPSS Inc., USA.

Willems, O.W., S.P. Miller and B.J. Wood (2003). Aspects of selection for feed efficiency in meat producing poultry. Worlds Poult. Sci. J., 69: 77-88. 
تأثير شكل العليقة علي أداء سلالتين من كتاكيت اللحم

أحمد عبد الوهاب عنب(')، فاروق حسن عبده(1)، جمال عبد الستار زناتي(")،

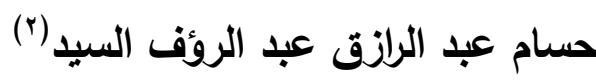

(1) قسم إنتاج الدواجن والأسماك - كلية الزراعة - جامعة المنوفية (ץ) وزارة الزراعة واستصلاح الأراضي الأنياك

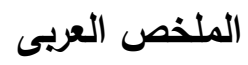

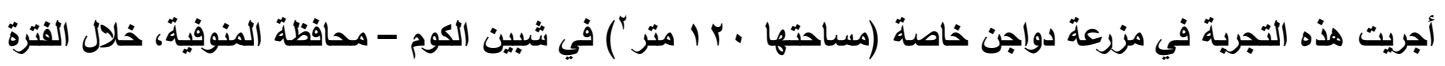

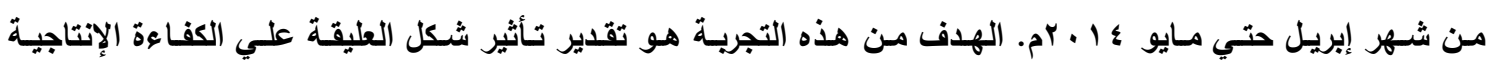

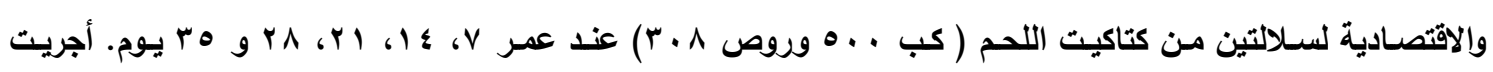

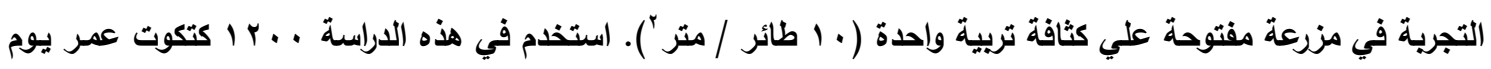

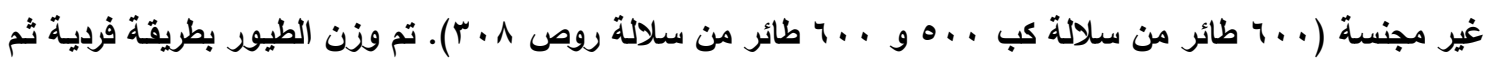

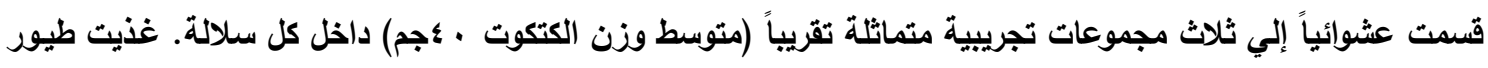

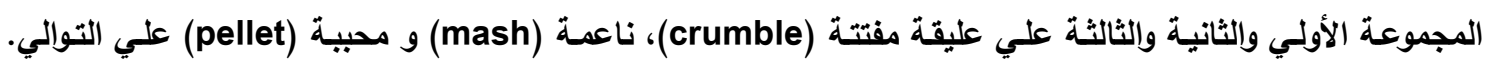

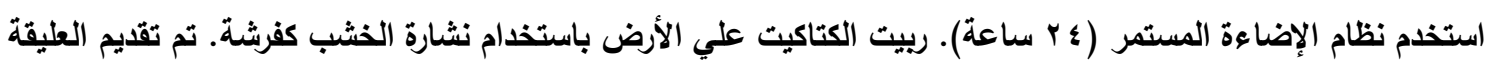

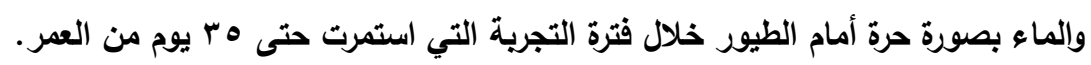
تم دراسة الصفات التالية: أوزان الجسم عند الأعمار المختلفة، معدلات النمو، الغذاء المستهلك، (كجم/ الطائر/ الدورة)، معدل تحويل الغذاء، \% النفوق، \% التجانس. والنتائج المتحصل عليها أوضحت أنج: 1-طيور سلالة كب التي غذيت علي عليقة ناعمة (mash) كانت أعلي وزن جسم عند التسويق (هب يوم من العمر).

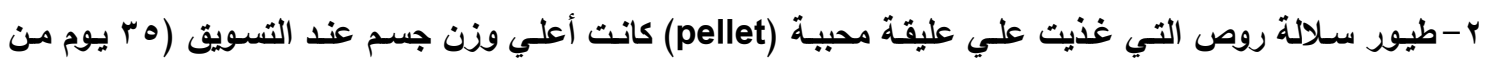
(العمر).

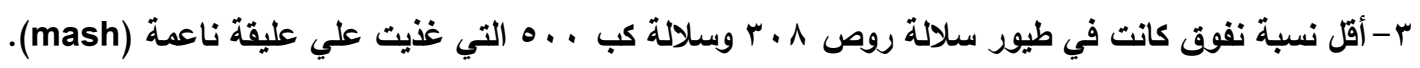

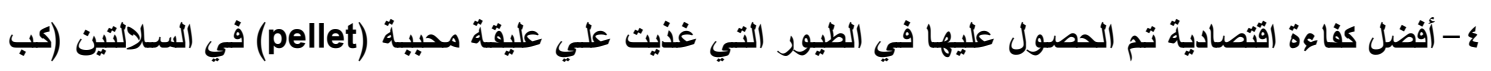

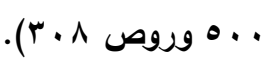

أسماء السادة المحكمين كلية الزراعة - جامعة كفر الثيخ أ.د/ حسن حسن عبدالله يونس ألس أ.د/ سيد عبدالفتاح عبدالرحمن لية الزباعة - جامعة المنوفية 